Florian Siegl

University of Helsinki

\title{
The counterfactive mood in Forest Enets and its origin
}

The description of the counterfactive mood (Siegl 2013: 298) reported that this mood has fallen out of use in the speech of the last generation of fully fluent speakers. Although it is remembered and some examples from elicitation are attested, it could no longer be found in transcribed narratives representing the language of the last fully fluent speakers recorded between 2006 and 2011. By contrast, the counterfactive mood is very frequent in narratives from the parental generation on which this study is based. Apart from a functional description and an analysis, the article discusses the history of this mood. The article ends with a collection of thoughts concerning the history of the Proto-Samoyedic tense system, as this mood is historically closely connected to the Proto-Samoyedic aorist marker ${ }^{*} \eta \not ̊$.

1. The counterfactive mood - introductory remarks

2. The counterfactive mood in older Forest Enets texts 2.1. Examples in conjugation I 2.1.1. Locative and possessive predication

2.1.2. Predicative attributive clause

2.1.3. Intransitive verbs

in conjugation I

2.1.4. Transitive verbs in conjugation I

2.2. Examples in conjugation II

2.3. Unclear examples

2.4. Conclusions
3. Parallels in other Northern Samoyedic languages

3.1. Tundra Enets

3.1.1. Labanauskas'

interrogative conjugation

3.1.2. Helimski's account of -ina

3.2. Nganasan

4. Comparative analysis

5. Instead of a conclusion: aorist ${ }^{*}-\eta \mathfrak{a}$

$\rightarrow$ interrogative - areality or else? 


\section{I.The counterfactive mood - introductory remarks}

The counterfactive mood in Forest Enets belongs to a series of minor and less-frequently appearing moods. It is almost extinct in the language of the generation of speakers underlying Siegl (2013). Although the speakers recognize this mood and can produce forms in elicitation, it has fallen out of use. ${ }^{1}$ By contrast, this mood is reasonably well attested in the language of the parental generation. Both structurally and semantically, this mood is different from morphosyntactically regular moods such as the necessitative (Siegl 2013: 284, 307), and in the following a short overview of its peculiarities will be provided. The counterfactive mood is built on the negative auxiliary $i$ - and the negated lexical verb, which surfaces, as expected, in the connegative (Siegl 2013: 298, 302ff). In principle, a specialized mood marker - ya seems to be segmentable, as the following example suggests:
(1) eńči $i-\eta a$
kadi- $r^{2}$
torsixun
person NEG.AUX-CTF.3SG be.ill-FREQ.CN so.LOC.SG
'Of course, a person would be ill in such circumstances.' [71:53]

However, this segmentation is incorrect, as $-\eta a-$ occasionally also $-\eta \mathbf{i}-$ is not attested in the affirmative. When appearing on a finite lexical verb, - $y a$ is an allomorph of the frequentative aspect (see Siegl 2013: 270ff). Although homonymous, the modal function and the aspect function cannot be conflated and both functions must analyzed separately. In the following, the aspectual function will be shortly discussed. As already mentioned, - ya appears only on finite verbs:
(2) toпијu
tina ${ }^{2}$
okan
kadi-ya-č
summer.ADV reindeer.PX.PL.1PL many.PROL be.ill-FREQ-3PL.PST
'In the summer, our reindeer were very ill.' [LDB Plundered Sled]

In negation, the suffix - ya is dropped and its allomorph $-r$ appears on the lexical verb; person marking is, as expected, transferred to the auxiliary verb. Example (3) demonstrates again that the homonymous - ya from examples (1) and (2) belongs to two different morphemes. Functionally, (2) and (3) belong together as (3) is the negated variant of (2):
(3) $b u \quad n ́ i$
kadi- $r^{2}$
3SG NEG.AUX.3SG
be.ill-FREQ.CN
'He is not ill.' 
In the following example, the regular negation of the perfect tense, which requires the negative auxiliary, is shown. In the affirmative, the perfect suffix - $b i$ appears on the finite verb (4a); in negation, it is transferred to the negative auxiliary $(4 \mathrm{~b})$ :

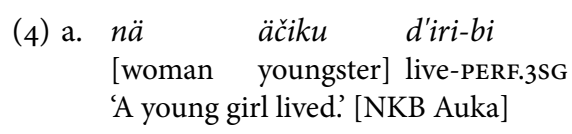

$\begin{array}{llll}\text { b. } b u d u^{2} i-b i-{ }^{2} & d^{\prime} \text { odi-r } & \text { kuxuru- }{ }^{2}[\ldots] \\ \text { 3PL NEG.AUX-PERF-3PL } & \text { go-FREQ.CN } & \text { PRO.NEG-LAT } \\ \text { 'They have not gone anywhere...' [ZNB Weekend] }\end{array}$

Based on the data presented, the introductory example (1) can now be approached for reanalysis. Although it is possible to isolate a potential mood marker $-y a$, the whole negated predicate must be analyzed as the meaningbearing unit, as similar forms in the affirmative are absent. Consequently, the counterfactive mood consists of a complex predicate:
(1) eńči $i-\eta n a$
kadi-r?
torsixun
person [NEG.AUX-CTF.3SG be.ill-FREQ.CN] so.LOC.SG
'Of course, a person would be ill in such circumstances.' [71:53]

Turning from morphology to semantics, several equally unusual features accompany the counteractive mood. Although the underlying construction is morphosyntactically clearly negative, as both a negative auxiliary and a lexical verb in the connegative appear, its meaning is not negative. Furthermore, the Russian translations of examples containing this mood offered by native speakers were never negative. Very often, they are translated with the addition of the Russian adverb конечно 'of course', as is the case for the translation of example (1) in the text collection Энецкие тексты (Sorokina \& Bolina 2004; further ET): “Человек, конечно, будет болеть при таких условиях."

Concerning its function, examples with the counterfactive mood appear in situations when something has happened or is done against a general expectation of the speaker. A certain mirative connotation (see DeLancey 1997) may be constructed in several examples, but the counterfactive - $y a$ does not prototypically encode mirativity to motivate such a label. Therefore, the label counterfactive was chosen in Siegl (2013). ${ }^{2}$ 
Finally, as is the case with several other moods in Forest Enets, the counterfactive mood seems to possess an inherent tense value. Whereas in English translations, present and past tense are possible (occasionally also future), in all examples which were analyzed for Siegl (2013), tense and aspect morphology were absent; all examples encountered were in the aorist. ${ }^{3}$ The task of this more detailed study is to compare this description with data from ET.

\section{The counterfactive mood in older Forest Enets texts}

As already stated in the introduction, the data for this investigation derives exclusively from the published texts in ET. The analysis of the Forest Enets part of ET produced 55 examples. ${ }^{4}$ However, the attested data is severely biased and as such not representative of Forest Enets. Out of 55 examples, 45 come from the idiolect of Nikolaj Pal'čin, the major consultant of both N. Tereščenko and I. Sorokina. ${ }^{5}$ In particular, his stories 8, 12 and 61 contain extraordinarily many examples in this mood. Another eight examples are from other speakers from the parental generation. ${ }^{6}$ Two examples in ET come from speakers who are representatives of the current generation of speakers, but the recordings were made before the turn of the millennium.

The discussion of attested data is organized as follows. In section 2.1, representative examples encoded in conjugation I will be discussed. In 2.2, all examples in conjugation II will be presented as their number is small; examples in conjugation III are absent in the data available. In section 2.3, a number of unclear examples are presented. The data is given following the same principles as in Siegl (2013); obvious errors and misprints are corrected and examples are normalized where required.

\section{I. Examples in conjugation I}

The following section contains examples in conjugation I (trad: subjective conjugation). As verbal endings of conjugation I can be found on predicates belonging to several different predicate types, a more fine-graded syntactic overview is required. 


\section{I.I. Locative and possessive predication}

Both locative predication (locative copula yaš 'be located at') and possessive predication (tonäš 'exist') 7 are compatible with the counterfactive mood. In Forest Enets, both predicate types belong to the sphere of intransitive predication:
(5) mensida
mäknida
$i-\eta a$
ya-
old.woman.PX.3SG house.LOC.SG.PX.GEN.3SG [NEG.AUX-CTF.3SG be $_{\text {Loc }}{ }^{-C N}$ ]
'His wife, of course, is at home (Lit: in his/her house).' [12:5]
(6) $[\ldots]$ tukada i-na tonä-?
axe.PX.3SG [NEG.AUX-CTF.3SG exist-CN]
'Of course he has an axe.' [78:11]

\section{I.2. Predicative attributive clause}

A particularly interesting syntactic example in the sphere of non-verbal predication is found below. Before this example can be approached, some further background information concerning non-verbal attributive predication is necessary. In Forest Enets, predicative adjectives may be encoded verbally under certain conditions (see Siegl 2013: 335-336). When an attributive non-verbal predicate is negated, a negative construction with the negative auxiliary in ńe+vx and the locative copula yaš in the connegative must be added to the non-verbal predicate:

(7) a. koru poju

knife sharp.3SG

'The knife is sharp'. [ZNB I 32]

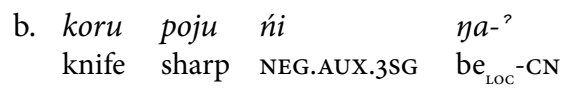

'The knife is not sharp (lit: the knife is sharp, it is not)'. [ZNB I 32]

In the following example, which is semantically again affirmative, the relationship between negation and the counterfactive mood can be seen particularly well. Compare examples (7) and (8):

$\begin{array}{llll}\text { pagii koru } & \text { i-ya } & \text { poi } & \eta a^{-2}[\ldots] \\ \text { [cut.cloth.PTCP.PFT knife] } & \text { [NEG.AUX-CTF.3SG } & \text { sharp } & \text { be }_{\text {Loc }} \text {-CN] } \\ \text { 'Of course, a knife for cutting cloth is sharp'. [12:103] } & \end{array}$




\section{I.3. Intransitive verbs in conjugation I}

In the following, several examples for intransitive verbs encoded in conjugation I are provided:

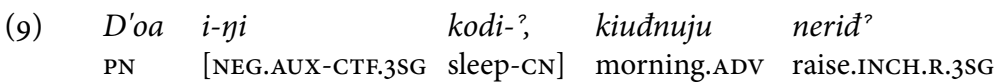

'Of course, D'oa slept. In the morning, he rose.' [14:2]

(10) obu d'od'igon d'idida i-ni pi-?

[what ${ }_{[\mathrm{GEN}]}$ time.LOC.SG] kettle.PX.3SG [NEG.AUX-CTF.3SG cook-cN] 'After a while, his kettle (=his food) is cooking, of course.' [9:21]

(11) onai nä yoxuđa bugulaš, i-na ad-? real woman foot.PX.DU.3SG stretch.CON[NEG.AUX-CTF.3SG sit-CN] 'The Enets woman, stretching her feet, of course, sat down.' [12:45]

(12) $[\ldots] \quad i-\eta a-d^{2} \quad k o m a-?$ ted [NEG.AUX-CTF.1SG want-CN] reindeer.LAT.SG 'Of course, I want a reindeer'. [52:21]

\section{I.4. Transitive verbs in conjugation I}

A number of examples with ambitranstive, transitive and ditransitive verbs in conjugation I are subsumed here: ${ }^{8}$

(13) $\eta u-g o \quad$ i-ya-i $i^{2} \quad$ nig-? ${ }^{2} \quad[\ldots]$

grass-INDEF ${ }_{[A C C]}[$ NEG.AUX-CTF-1DU gather-CN]

'Of course, we two are gathering some grass.' [12:26]

(14) D'oa i-ya oo- $r^{2}$

PN [NEG.AUX-CTF.3SG eat-FREQ.CN]

'D'oa, of course, ate.' [8:33]

(15) busi mana šiđđi $i^{2} i-\eta$ a- đ? boira- ${ }^{2} \quad[\ldots]$

old.man say.3SG 2DU.ACC [NEG.AUX-CTF.1SG take.across.CN

'The old man said: "Of course I will take you two across (the river).' [13:54]

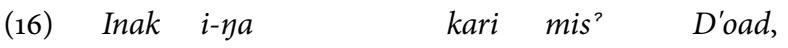

PN [NEG.AUX-CTF.3SG fish ${ }_{[a c c]}$ give.CN] PN.LAT.SG

kari $m i \dddot{a}$

fish $_{[\text {[Acc] }}$ give.3sG

'Inak, of course, gave fish to D'oa, he gave fish.' [8:39] 


\subsection{Examples in conjugation II}

In the following, all examples for the counterfactive mood in conjugation II found in ET are subsumed:

(17) ńib'o-da i-na-đa mät čuri-? mother-PX.3SG [NEG.AUX-CTF-SG.3SG chum.LAT.SG carry-CN] 'His mother, of course, he carried her into the chum.' [8:95] ${ }^{9}$

(18) busi čiki nä äči-xuđa

old.man this [girl youngster]-PX.ACC.DU.3SG

i-ya-xuda ota-? nitatida

[NEG.AUX-CTF-DU.3SG feed-CN] rest.CAUS.PL.3SG

'Of course, the old man fed the two girls. He let them rest.' [12:213]

(19) onai nä mana mäm i-ya-u

real woman say.3Sg chum.PX.ACC.1SG [NEG.AUX-CTF-SG.1SG

$\mathrm{ko}^{2} \quad[\ldots]$

find-CN]

'The Enets woman said: “Of course, I will find my chum...' [15:41]

(20) eńči mana $i-\eta a-u$ šeda-? bađa-ad

person say.3SG [NEG.AUX-CTF-SG.1SG make-CN] speak $_{\mathrm{NIZ}}$-PX.GEN.2SG šer $[\ldots]$

PP

'The person said: 'Of course I will follow your word...' [60:52]

(21) odid ko-xi $i^{2} \quad i-\eta a-d i \quad k o-^{2} \quad o d i d$ plant $_{[\mathrm{ACC}]}$ find-3DU [NEG.AUX-SG.3DU find-CN] plant $_{[\mathrm{AcC}]}$

'They two found a plant, of course, they two found it.' [61: 8]

(22) $a n^{7}$ täxä ńiu $\quad y a^{?} \quad i-\eta i-u$

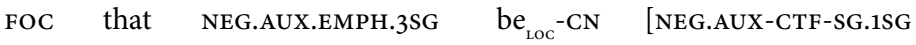
tudulu-?

recognize-CN]

'And so, this over there, of course, I recognize it.' [66:70]

(23) mod' mana- d’ d'ire-d koma-ńidu $i-\eta i-u$

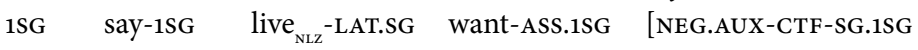

mär mä-?

quickly make-CN]

'I said: "I want to live, of course. I will do it quickly." [66:34] 


\subsection{Unclear examples}

The following two examples, both from one and the same narrative by Nikolaj Pal'čin, are problematic. As these forms cannot be compared with original sound recordings to clarify whether they would be instances of disfluency, they must be interpreted as they appear in the text collection.

Here, in contrast to all examples from above, the negative auxiliary is not followed by a negated lexical verb and in both instance ina appears as a free particle: ${ }^{10}$

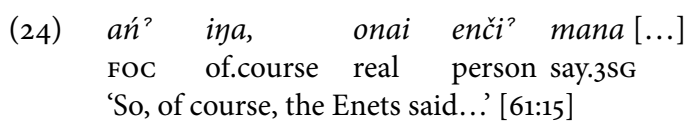

The second example looks indeed more like an instance of disfluency; first, the demonstrative to is not attested in my materials as a freestanding element but only in equivalents of English 'during, in this period' as to d'od'igon. Second, the echo question is equally problematic. ${ }^{11}$ This means that this example remains currently incomprehensible:

\begin{tabular}{|c|c|c|}
\hline $\begin{array}{l}\text { to } \\
\text { that }\end{array}$ & $\begin{array}{ll}\text { mensi-r } & \text { ina } \\
\text { old.woman-PX.2sG of.course }\end{array}$ & $\begin{array}{l}\text { koma-sau, } \\
\text { want-PROB }_{\mathrm{PST}} \cdot 3 \mathrm{SG}\end{array}$ \\
\hline
\end{tabular}

\subsection{Conclusions}

The preceding section presented examples for the counterfactive mood in conjugation I and II; examples in conjugation III are absent in ET. Although not mentioned separately, all examples represented here and as a matter of fact all attested examples in ET and my own materials show neither tense nor aspect morphology. ${ }^{12}$ Consequently, the counterfactive mood allows only an aorist interpretation. Returning to the example mentioned in the introduction, the frequentative allomorph - $y a$ and the counterfactive mood element $-\eta a$ are suspiciously close; further, the aorist tense interpretation of the counterfactive mood is suspiciously close to the assumed Proto-Samoyedic aorist marker ${ }^{\star}-\eta a ̊$. This discussion will be taken up again later. For the time being, a syntactic peculiarity of the counterfactive complex predicate must be mentioned here. In standard negation as investigated in Siegl (in print), the negative verb and the connegative form 
a tight constituent, which cannot be split. In sharp contrast, in several examples above, one could observe how another constituent can split the complex predicate. This may be a predicative adjective (26), an object (27), an adjunct (28) or an adverb (29):

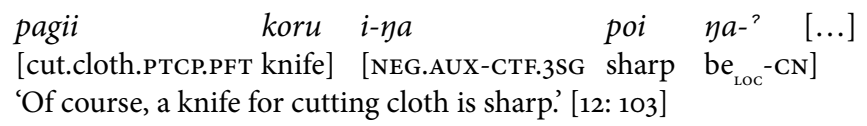

\begin{tabular}{|c|c|c|c|}
\hline $\begin{array}{l}\text { Inak } \\
\text { PN }\end{array}$ & $\begin{array}{l}i-\eta a \\
\text { NEG.AUX-CTF.3SG }\end{array}$ & $\begin{array}{ll}\text { kari } & \text { mis }^{2} \\
\text { fish } & \text { give.cNl }\end{array}$ & $\begin{array}{l}\text { D'oad, } \\
\text { PN.LAT.SG }\end{array}$ \\
\hline $\begin{array}{l}\text { kari } \\
\text { fish }_{\text {acce }}\end{array}$ & $\begin{array}{l}m i^{2} \ddot{a} \\
\text { give.3SG }\end{array}$ & & \\
\hline
\end{tabular}

$\begin{array}{llll}\text { ńib'o-da } & i-\eta a-d a & \text { mät } & \text { čuri-' } \\ \text { mother-PX.3SG } & \text { [NEG.AUX-CTF-SG.3SG } & \text { chum.LAT.SG } & \text { carry-CN] } \\ \text { 'His mother, of course, he carried her into the chum.' [8:95] }\end{array}$

\begin{tabular}{|c|c|c|c|c|}
\hline $\begin{array}{l}\bmod ^{\prime} \\
1 S G\end{array}$ & $\begin{array}{l}\text { mana- } d^{2} \\
\text { say-1SG }\end{array}$ & $\begin{array}{l}\text { d'ire-d } \\
\text { live }_{\mathrm{NL}} \text {-LAT.SG }\end{array}$ & $\begin{array}{l}\text { koma-ńidu? } \\
\text { want-Ass.1SG }\end{array}$ & $\begin{array}{l}i-\eta i-u \\
\text { [NEG.AUX-CTF-SG.1SG }\end{array}$ \\
\hline $\begin{array}{l}\text { mär } \\
\text { quickly }\end{array}$ & $\begin{array}{l}\text { mä-? } \\
\text { make- }\end{array}$ & & & \\
\hline
\end{tabular}

Apart from these examples, there are several more instances attested in ET, e. g. [8:45], [10:19], [12:8], [12:47], [12:292], [12:143] and [32:17]. Still, with the exception of example [32:17], all instances, again, derive from the speech of Nikolaj Pal'čin. This makes an evaluation of this syntactic peculiarity impossible. Although this feature is prominent in his idiolect, the question of whether this is representative of Forest Enets in general cannot be answered satisfactorily. I was at least able to identify another example in a transliterated narrative from a different speaker of the same generation. Here, the complex predicate is split by an adjunct:

$$
\begin{array}{llll}
\text { aija-đa } & i-\eta i & \text { tod'ai } & \eta a^{-} \\
\text {body-PX.3SG } & \text { [NEG.AUX-CTF.3SG } & \text { feather.Com } & \text { be }_{\text {Loc }} \text {-CN } \\
\text { 'Of course, his body was covered with feathers.' [VNB Witch] }
\end{array}
$$

This demonstrates that this feature does not seem to be restricted exclusively to the idiolect of Nikolaj Pal'čin. Due to the lack of further data, a more thorough description remains impossible. 


\section{Parallels in other Northern Samoyedic languages}

In the following section, some potential cognates in other Northern Samoyedic languages will be sought. Whereas cognates seem to be absent in both Nenets languages, Tundra Enets and Nganasan show some interesting parallels. The cognates in the latter are to be found in the field of interrogativity.

\section{I. Tundra Enets}

Due to the absence of a comprehensive corpus, the situation in Tundra Enets can only be sketched. First, in the available texts reproduced in ET, the category under investigation could not be found. However, a number of paradigms and isolated example phrases can be found in Labanauskas' sketch grammar (Labanauskas 2002). Further examples derive from Helimski's unpublished grammatical notes on Tundra Enets. ${ }^{13}$ As both authors present diverging data, their accounts will be presented separately. ${ }^{14}$

Before we have a look at this data, a short introductory note is in order. Similarly to Forest Enets, the Tundra Enets etymological cognate of the Proto-Samoyedic aorist marker ${ }^{*}$ - $y a ̊$ is restricted to the same inflection class and, at least synchronically, cannot be considered a tense marker. The following examples show that we are dealing with the same frequentative aspect marker, which shows identical distribution of $-r$ and $-y a$ :

(31) TE
a. modi fiši-ya-đo?
1SG laugh-FREQ-1SG
'I am laughing.' [Labanauskas 2002: 42]
b. modi ńe-do? fiši-ro-?
ISG NEG.AUX-1SG laugh-FREQ-CN
'I am not laughing.' [Labanauskas 2002: 42]
(32) FE
a. tonuju
tina ${ }^{2}$
okan

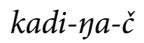
summer.ADV reindeer.PX.PL.1PL many.PROL be.ill-FREQ-3PL.PST
'In the summer, our reindeer were very ill.' [LDB Plundered Sled]
b. bu ńi
kadi- $r^{2}$
3SG
NEG.AUX.3SG
be.ill-FREQ.CN
'He is not ill.' 


\section{I.I. Labanauskas' interrogative conjugation}

In the section on interrogative conjugation in Tundra Enets, Labanauskas subsumed a number of different morphemes, which were grouped by onomasiological and not by semasiological principles. The first interrogative subparadigm in conjugation II with singular object reference shows a suffix $-b a$. This can also be negated regularly with the negative auxiliary in $i$-. Semantically, both past tense reference and interrogativity seem to be attested, which makes a past interrogative function quite likely:
a. modi fu-ba-bo
ISG put-IROG.PST-SG.1SG
'Did I put it?' [Labanauskas 2002: 60]
b. modi i-ba-bo funo-?
ISG NEG.AUX-IROG.PST-SG.1SG put-CN
'Did I not put it?' [Labanauskas 2002: 6o]

In addition, a clausal example can be found:
sira tia
ia
pođaroe
šio šito
tabada-ba?
'Who ordered you to harness a white reindeer?' [Labanauskas 2002: 61]

Labanauskas' next subparadigm, now in conjugation I, is based on a morpheme in -doba. This appears to be a combination of the future tense marker - $d o$ and the same past interrogative suffix - $b a$ mentioned above. Negation seems to operate regularly: ${ }^{15}$
a. modi kane-do-ba-do?
ISG go-FUT-IROG.PST-1SG
'Did I really go? (How could I go?)' [Labanauskas 2002: 60]
b. modi i-ba-do? kane-do-?
ISG NEG.AUX-IROG.PST-1SG gO-FUT-CN
'Did I really not go? (How could I not go?)' [Labanauskas 2002: 6o]

The next paradigms in Labanauskas' discussion are based on a morpheme ina, which matches the Forest Enets forms. In contrast to Forest Enets, Labanauskas' data shows both affirmative and negative forms: 
a. modi $d^{\prime} u^{2}-i \eta n a-b o$

ISG lose-IROG-SG.1SG

'Did I lose it? (How could I lose it?)' [Labanauskas 2002: 6o]

b. modi i-ina-bo d'osu-?

1SG NEG.AUX-IROG-SG.1SG lose-CN

'Did I not lose it?' [Labanauskas 2002: 60]

For this form, only one clausal example is given:
inexońi
sooe-do?, miiro
ote-ina-do
brother.LAT.SG ${ }_{\text {poss }}$.PX.GEN.1SG drive-1SG what $_{[\mathrm{AcC}]}$ wait-IROG-1SG
'I went to my brother, for what should I wait?' [Labanauskas 2002: 61]

Finally, Labanauskas mentions another form in this section. Based on its translation, it seems to be a past tense equivalent of the preceding form, but more morphological material is required. Again, negative forms seem to be possible. In contrast to the forms mentioned above, the formally affirmative form ( $38 \mathrm{a})$ is also rendered by a negated clause in Russian. The formally negative form ( $38 \mathrm{~b})$ at least has a negative auxiliary in this complex predicate:
a. modi kane-sii a-ina-đo?
ISG gO-IROG? be-IROG-1SG
'How could I not go?' [Labanauskas 2002: 60]
$\begin{array}{llll}\text { b. modi } & i \text {-sii- }\left(d o^{2}\right) & a-i \eta a-d o^{2} & \text { kane-? }^{?} \\ \text { ISG } & \text { NEG.AUX-IROG?-(1SG) } & \text { be-IROG-1SG } & \text { go-CN }\end{array}$
'How could I not go? Really, I could not go?' [Labanauskas 2002: 61]

The morphological structure of such complex modal predicates is indeed problematic. Other forms mentioned in this section show optional vx marking on the negative auxiliary, which were given in brackets:

(39) modi fu-dii a-ine-no

1SG put-IROG? be-IROG-PL.1SG

'How could I put many? (Really, I put many?)' [Labanauskas 2002: 61]

In other examples, however, vx marking is absent:

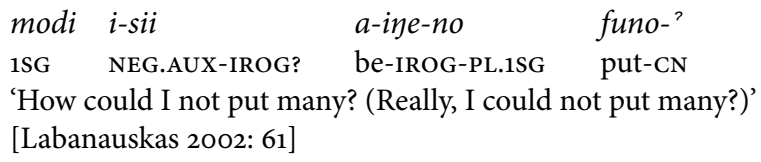


Due to scarcity of textual materials, a more detailed syntactic analysis remains impossible. In all attested examples (Labanauskas 2002: 61), the negative construction is not split by other constituents.

\section{I.2. Helimski's account of -ina}

Helimski's unpublished grammatical notes on Tundra Enets discuss a morpheme -ina, which he classified as an interrogative-predicative suffix. ${ }^{16}$
a. maminado 'Would you say?' ${ }^{17}$
b. ominado 'Would you eat?'
c. puo'inado 'Would you be fed?'
d. kaneinado 'Would you go?

Helimski's manuscript also contains examples showing standard negation:
a. ina-ro
$m e^{-?}$
NEG.AUX.IROG-SG.2SG make-CN
'Would you not do it?
b. mod'i ina-do? tu-? 1SG NEG.AUX.IROG-1SG make-CN 'Lest I come'.

What makes his account interesting is the fact that Helimski's data (41) presents two verbs that show irregular stem distribution, namely 'say' and 'go'. Their stems mam- and kane- suggest that the stems followed by -inaare the connegative forms. The glottal stop in example (41c) would also suggest this. If such an interpretation is correct, then we are dealing with an inverse negative construction that serves as a finite predicate. Otherwise, similar to Forest Enets, the potentially underlying complex predicate is semantically affirmative; an interrogative function is also clearly attested. When comparing Helimski's data with Labanauskas', it is somewhat surprising to see that in Helimski's account, this category is compatible with the future tense $-d a$ or the durative aspect - $g u$. In Labanauskas' data, only the future tense morpheme is mentioned, but in his examples for-doba the morpheme is complex and contains both the future tense marker as well as the past interrogative marker $-b a$ : 
(43) a. padodoina <write.FUT.IROG.3SG > He looks as if he is writing.'

b. tôtagudoina <read.DUR.IROG.3SG> 'He looks as if he is reading.'

Further, Helimski's manuscript contains several negative examples where the forms subsumed under predicative interrogative lack an interrogative translation. In such instances, the Forest Enets counterfactive interpretation becomes possible. Apart from (43), one finds the following examples, shown here in (44). (44a) and (44b) are semantically neither identifiable as interrogatives nor were they translated as such; (44c) however matches the expected pattern:
a. ńitoda śikoneda
pađodoina
3SG self.PX.GEN.3SG ${ }^{18}$ write.FUT.IROG.3SG
'He considers himself to be able to write.'
b. mod'i śikoneńi ${ }^{2} \quad$ kaneinađo?
1SG self.PX.GEN.1SG go.CN.IROG.1SG
nia texo tekare?
door $_{[\mathrm{GEN}]}$ back.LAT hide.R.3sG
'Apparently, I myself went and he hid behind the door.'
c. śio śī tabulaina.
who 1SG.ACC keep.IROG.3SG
'Who can hold me back?'

Finally, one example with - $b a$ from Helimski's manuscript is given here too. In contrast to ina, this morpheme was not labeled. Similarly to Labanauskas's example, Helimski's example also has a clear past tense interrogative function: ${ }^{19}$
(45) sira tia pođaroe šio šito tabađa-ba? white reindeer $_{[\mathrm{Acc.SG}]}$ harness.CON who 3SG.ACC order-IROG.PST.3SG 'Who ordered you to harness a white reindeer?' [Labanauskas 2002: 61]

(46) t'ike mekito tu-ba-do

DEM chum.ABL.PL come-IROG.PST-2SG

'Did you come out of these chums?' 


\subsection{Nganasan}

A potential cognate for the aforementioned Forest Enets and Tundra Enets forms in Nganasan can be found in the tensed interrogative series. More precisely, the aorist interrogative mood in $-\eta V$ appears to be relevant:

(47) маадя баң тогя-ңь?

why dog bark-IROG.AOR.3SG

'Why is the dog barking?' [NgJa 48]

(48) тубтугуй-ну-ң хотүрамту?

read-IROG-2SG letter.ACC.PX.3SG

'Is he reading his letter?' [NgJa 49]

Further, its negation is unproblematic:

\begin{tabular}{|c|c|c|}
\hline ма̄низе & әмны & $H u-H b l-p b \iota^{\prime \prime}$ \\
\hline because.of.what & here & NEG.AUX-IROG-2PL live-CN \\
\hline
\end{tabular}

Although we seem to be dealing with an etymological cognate, the functional variation is quite drastic. The interrogative function of Nganasan can be traced in Tundra Enets, but the Forest Enets counterfactive mood does not show any signs of interrogation. This relation seems to be meaningful and a comparative analysis will be attempted in the next section.

\section{Comparative analysis}

When comparing the Nganasan data with both Tundra and Forest Enets, it becomes obvious that Nganasan operates according to a different pattern. Although negation is asymmetric in the sense of Miestamo (2005), it is also symmetric (not in the sense of Miestamo (2005)), meaning that the Nganasan and Tundra Enets interrogative forms are negated regularly; morphological material appearing on the finite verb appears on the negative auxiliary too:

a. modi $d^{\prime} u^{2}-i n a-b o$

ISG lose-IROG-SG.1SG

'Did I lose it? How could I lose it? [Labanauskas 2002: 6o]

b. modi i-ina-bo d'osu-?

1SG NEG.AUX-IROG-SG.1SG lose-CN

'Did I not lose it?' [Labanauskas 2002: 60] 
The counterfactive mood in Forest Enets and its origin

(51) $\mathrm{Ng}$

а. маадя баң тогя-нь?

why dog bark-IROG.AOR.3SG

'Why is the dog barking?' [NgJa 48]

b. ма̄низе әмны ни-ңьь-ры"

because.of.what here NEG.AUX-IROG-2PL live-CN

'Why don't you live here?' [Tereščenko 1979: 262]

By contrast, Forest Enets, at least in the stages of the language for which material is available, has undergone change and apparently also simplification, and the historically negative forms were reanalyzed as an affirmative complex predicate:

(52) FE

$$
\begin{array}{lll}
D^{\prime} \text { oa } & i \text {-ya } & \text { oo- } r \\
\text { PN } & \text { [NEG.AUX-CTF.3SG } & \text { eat-FREQ.CN] } \\
\text { 'D'oa, of course, ate.' [8:33] }
\end{array}
$$

Concerning tensed interrogative moods, this investigation has further shown that the three Taimyrian languages show a higher degree of convergence. Nganasan has a variety of interrogative forms in different tenses (Katzschmann 2008: 429ff). Here only aorist and past forms are given:

(53) $\mathrm{Ng}$

а. маадя баң логя-нь?

why dog bark-IROG.AOR.3SG

'Why is the dog barking?' [NgJa 48]

b. куниа сыты конь-бы

PRO.LAT 3SG go-IROG.PST.3Sg

'Where did he go?' [NgJa 49]

Closest to Nganasan is Tundra Enets, which has a rather similar tensed interrogative mood system. ${ }^{20}$ Again, only forms for past and aorist tense reference are given:

(54) TE

a. koma-ba-do,

$i-b a-d o$,

met

want-IROG.PST-2SG

NEG.AUX-IROG.PST-2SG

chum.LAT.SG

kane-da- đo ${ }^{2}$

go-FUT-1SG

'Whether you want or not, I will go into the chum.'

[Labanauskas 2002: 61]

b. modi d'u'-ina-bo

1SG lose-IROG-SG.1SG

'Did I lose it? How could I lose it? [Labanauskas 2002: 6o] 
In contrast, Forest Enets has only one tensed interrogative mood (Siegl 2012; 2013: 285), which is not shared with Nganasan and Tundra Enets, but with the Nenets languages:

$\begin{array}{llll}\text { (55) FE } & \begin{array}{l}\text { obu- } \check{s} \\ \text { what-TrSL }\end{array} & \begin{array}{l}\text { Potabu-xud } \\ \text { Potapovo-ABL.sG }\end{array} & \begin{array}{l}\text { to-sa-d } \\ \text { come-IROG-2SG }\end{array}\end{array}$

'Why did you come from Potapovo?' [ZNB I 69]

(56) TN pidar xinna pađnว-sa-n

2SG PRO.LOC write-IROG-2SG

'Where did you study?' [TMP I 1]

Further, all three Taimyrian Samoyedic language show a clear extension concerning the development of the assumed Proto-Samoyedic aorist marker ${ }^{*}$ - $a ̊$ into an interrogative aorist mood marker. Whereas the Nganasan development aorist $\rightarrow$ interrogative aorist mood is comparatively well known (see e. g. Katzschmann 2008: 412-413 for a survey), there are clear parallels in Tundra Enets, which so far seem to have been overlooked:

(57) Ng тубтугуй-ну-н хотүрәмту?

read-IROG-2SG letter.ACC.PX.3SG

'Is he reading his letter?' [NgJa 49]

(58) TE
inexońi
sooe-do
brother.LAT.SG poss .PX.GEN.1SG drive-1SG what ${ }_{\text {[Acc] }} \quad$ wait-IROG-1SG
'I went to my brother, for what should I wait?' [Labanauskas 2002: 61]

Further, Forest Enets should also be subsumed in this grammaticalization scenario, but Forest Enets has gone much further than Ngansan and Tundra Enets. Although morphosyntactically negative, the category itself cannot be separated from the negative auxiliary any longer and the complex predicate serves as the meaning-bearing unit. Second, although the category is morphosyntactically negative, it is semantically affirmative. Third, an interrogative function can no longer be attached to this category. Fourth, interrogative intonation is absent. ${ }^{21}$ To be sure, the polarity switch from negative to affirmative must be considered the crucial step separating the Forest Enets form from its cognates in Tundra Enets and Nganasan. ${ }^{22}$ Apparently, the counterfactive mood construction derives from the transition of a negative echo question 'did $\mathrm{X}$ not do' to an affirmative modal ' $\mathrm{X}$ did do so contrary to my expectation', which has then acquired a constructional meaning 'of course $\mathrm{X}$ did so, contrary to my expectation': ${ }^{23}$ 
(59) FE D'oa i-na oo- $r^{2}$

PN [NEG.AUX-CTF.3SG eat-FREQ.CN]

'D'oa, of course, ate.' [8:33] ( $\leftarrow$ D'oa did not eat, did he?)

As the data has shown, the similar function of $-\eta V$ in the languages under discussion is hardly an instance of chance. Further, it is unlikely that the suffix $-\eta V$ is anything other than the reflex of the Proto-Samoyedic aorist marker ${ }^{\star}-\eta a ̊$. The Enets data has not been discussed in print so far, as these forms have remained unnoticed. In this respect, it appears that the interrogative function of the old Proto-Samoyedic aorist marker ${ }^{\star}-\eta a ̊$ is attested not only in Nganasan, as was previously known, but to varying degrees also in Tundra and Forest Enets.

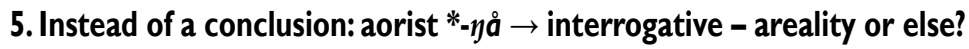

The aforementioned apparent etymological parallels between Forest Enets, Tundra Enets and Nganasan, which are absent from the Nenets languages (and apparently from Southern Samoyedic too), impose several questions which are beyond the scope of this paper. The gradual demise of interrogativity connected to this form does, in principal, reflect the areal proximity and the potential contact history of the three Taimyrian Samoyedic languages. It does not come as a surprise to see that Tundra Enets and Nganasan are much closer than Forest Enets to any of the two other languages. Still, this point holds several questions for future research. The fact that the Proto-Samoyedic aorist marker now shows related interrogative aorist functions in three Northern Samoyedic languages is intriguing. In principal, this would permit two speculative interpretations at the current moment. A conservative approach would most likely attempt to explain this feature being of recent origin, of an areal nature and perhaps of individual or at best contact-induced origin in the languages under discussion. Another and clearly more radical approach would attribute this development to linguistic prehistory and early shared innovations in Enets and Nganasan, which date to a period long before Taimyrian areality. Initially, such an assumption does not look too impossible given the fact that the history of Proto-Samoyedic tenses and the development of interrogative moods now show similar grammaticalization paths. Whereas in Forest Enets and Nenets languages the Proto-Samoyedic past tense marker ${ }^{*}$-så has developed into an interrogative mood with past tense reference, in Nganasan 
the Proto-Samoyedic aorist marker ${ }^{\star}$ - $\eta a ̊$ was grammaticalized as an interrogative mood with aorist reference. The accumulated data above suggests that the Nganasan innovation ${ }^{\star}$ - $y a ̊$ aorist $\rightarrow$ interrogative aorist mood has also happened in Tundra Enets and shows reflexes in Forest Enets.

\begin{tabular}{|l|l|l|l|l|}
\hline Proto-Samoyedic tense marker & $\begin{array}{l}\text { Forest } \\
\text { Enets }\end{array}$ & $\begin{array}{l}\text { Tundra } \\
\text { Enets }\end{array}$ & Nganasan & $\begin{array}{l}\text { Tundra } \\
\text { Nenets }\end{array}$ \\
\hline $\begin{array}{l}\text { Proto-Samoyedic past tense } \\
\rightarrow \text { interrogative past tense }\end{array}$ & + & - & - & + \\
\hline $\begin{array}{l}\text { Proto-Samoyedic aorist tense } \\
\rightarrow \text { interrogative present tense }\end{array}$ & + & + & + & - \\
\hline
\end{tabular}

Table 1: Development from tense to tensed interrogative marker

Although currently only a highly speculative proposal, if the grammaticalization aorist $\rightarrow$ interrogative aorist mood is indeed an older and shared development, it could have implications for the genetic grouping of Samoyedic. Whereas the Enets and Nenets languages are generally seen as most closely related in both taxonomies (see Janhunen 1998), the interrogative function of ${ }^{*}$ - $y a ̊$ separates the Nenets languages clearly from the Enets languages and Nganasan. In this point, the Enets languages and Nganasan are indeed very close and much closer than the Nenets languages to the Enets languages.

In the light of this paper, the development of the Proto-Samoyedic aorist suffix ${ }^{*}$-yå and the Proto-Samoyedic past tense marker ${ }^{*}$-så as subsumed by Mikola (2004: 115-116) needs to be revised substantially. The resulting historical questions are reserved for the specialists.

Florian Siegl

Finno-Ugrian Studies P.O. Box 24, 00014 University of Helsinki $<$ florian.siegl@helsinki.fi>

\section{Notes}

1. As a matter of fact, transliterations of narratives from a speaker of the current generation (collected be me in Potapovo in 2007 but unprocessed until late fall 2014 for a variety of reasons) produced several examples for this mood in spontaneous speech. All examples follow the pattern as found in the speech of the parental generation. 


\section{The counterfactive mood in Forest Enets and its origin}

2. Although Irina Sorokina has been aware of this morpheme and examples appear in the text collection, the co-authored dictionaries and her grammar, a description is absent. In her grammar (Sorokina 2010: 390-391), forms in ini appear in the section on particles. In addition, other negative auxiliaries were classified as particles, which is a gross misinterpretation. Some preliminary observations on ini can be found in a grammatical comment in ET (page 46-47). In Tereščenko's writings, such as her sketch grammar on Forest Enets (1966) and her comparative syntax (1973), examples for this construction are absent.

3. Apart from the few instances that appeared in my own corpus of contemporary Forest Enets (all representing data from elicitation), this analysis was based on several transliterated recordings featuring speakers from the parental generation.

4. [8:23], [8:33], [8:39], [8:45], [8:53], [8:95], [8:102]; [9:21], [9:50], [9:55], [9:68]; [10:19]; [12:5], [12:8], [12:26], [12:45], [12:47], [12:64], [12:94], [12:103], [12:125], [12:143], [12:181], [12:213], [12:214], [12:269], [12:292]; [13:54], [13:8]; [14:2]; [15:41], [15:48]; [23:12], [23:40]; [32:17], [38:50]; [45:8], [45:25]; [52:21], [52:26]; [60:52]; [61:8], [61:15], [61:32], [61:39], [61:42], [61:50]; [66:34], [66:70]; [71:38], [71:53], [71:68]; [78:11], [78:11], [78:38].

5. The Forest Enets speech community's criticism of the speech of Nikolaj Pal'čin has been addressed in Siegl (2013: 64-65) and should be consulted for further background information.

6. There are several more instances in other unpublished narratives from the parental generation which the author has transcribed with several Forest Enets assistants. Quantitatively, these narratives represent, again, the speech of Nikolaj Pal'čin and to a lesser degree another speaker from the parental generation. With the exception of one example, this data has not been brought into the corpus used for this investigation.

7. The difference between existential and possessive predication is encoded by PXmarking on the subject. A PX-marked subject triggers a possessive reading; a nonpossessed NP together with a locative adverb must be understood as existential (see Siegl 2013: 334ff).

8. This is intended to re-emphasize my position that transitivity and conjugation II do not go hand in hand in Forest Enets and that the function of conjugation II (trad: objective conjugation) is concerned with information structure (Siegl 2013: 249ff).

9. The first NP ńib'oda represents a possessive Tundra Nenets form. The regular lexeme for 'mother' in Forest Enets is $\ddot{a} \ddot{a}+\mathrm{PX}$.

10. In fact, these two examples would support Sorokina's interpretation mentioned in footnote 1 . As these examples are outnumbered by regular negative constructions, it is unlikely that they should be understood as instances of prototypical use.

11. The element isiu is classified by Sorokina as another particle (Sorokina 2010: 390391); in Siegl (2013: 297f) as a mood marker of the assumptative mood (based on the negative auxiliary $i$-) which occasionally follows the connegative verb. The fact that $i s i u$ appears here freestanding after a finite verb is problematic for both Sorokina's and Siegl's account and would require the original recording to see whether any meaningful intonation breaks would help to segment this example.

12. Unsurprisingly, all attested examples are affirmative.

13. Both accounts are based on Tundra Enets spoken in and around Voroncovo. 
14. Labanauskas' data was published in Cyrillic script. These examples have been transliterated following my Forest Enets conventions. English translations of the examples follow Labanauskas' Russian translation.

15. For this form, too, numerous examples are given, but these do not contribute to this discussion and are therefore not reproduced.

16. In the manuscript -iпа [вопр.-преди.?]. The manuscript represents Helimski's sorted reading notes but cannot be called a grammar in the strict sense of the term as inflectional nominal morphology as well as syntax remained uncovered. I have cited only forms that are comprehensible from a Forest Enets perspective. Helimski's transcription is unaltered, while translations from Russian are mine. The glossing is also mine, as the manuscript does not contain morphological information.

17. Helimski's translations contain the Russian conditional particle $\sigma b l$, which is followed here. Whether this really implies a modal connotation or serves as a rough translation of the interrogative function cannot be answered.

18. Preliminary glossing and translation; the function of this and the related form below are not clear as similar forms are not attested in Forest Enets.

19. All examples with $-b a$ in his manuscript are affirmative.

2o. It appears that the Tundra Enets interrogative forms in $-b a$ are indeed the etymological cognates of the Nganasan past tense interrogative forms in $-b V-/-x V$ - (Katzschmann 2008: 430). Consequently, Mikola's attempt to reconstruct the Proto-Samoyedic tense system must be dismissed. Contrary to his assumption, Tundra Enets has not preserved the Proto-Samoyedic past tense marker ${ }^{\star}$-så in this function: "Auch das Enzische hat PS *-så- als Interrogativzeichen bewahrt. Prokof'jew und Tereščenko haben einige Formen des Interrogativs aus der Bajicha-Mundart aufgezeichnet [...]. Aus der Chantaika Mundart haben wir keine Beispiele für den Interrogative, doch kann seine Existenz postuliert werden" (Mikola 2004: 115). The resulting implications must be postponed for the time being.

21. See Siegl (2012) for some remarks on intonation and interrogation.

22. Siegl (in print) discusses other examples which seem to have undergone a similar polarity switch development.

23. Note that the Tundra Enets examples (43) and (44a,b) point toward a development into the same direction. Strikingly similar examples from Nganasan were presented by Wagner-Nagy (2011: 132).

\section{Glossing}

\section{Forest Enets}

\begin{tabular}{|c|c|c|c|}
\hline [GEN] & non-possessed case & CTF & counterfactual \\
\hline $\mathrm{ADV}$ & adverbializer & FOC & focus particle \\
\hline Ass & assumptative mood & FREQ & frequentative \\
\hline $\mathrm{be}_{\mathrm{LOC}}$ & locational copula & $\mathrm{INCH}$ & inchoative aspect \\
\hline $\begin{array}{l}\text { LoC } \\
\text { CAUS }\end{array}$ & causative & INDEF & indefinite marker \\
\hline $\mathrm{CN}$ & connegative & LAT & lative case (postposition) \\
\hline $\mathrm{COM}$ & comitative & LAT.SG & lative singular \\
\hline $\mathrm{CON}$ & converb & LOC.SG & locative singular \\
\hline
\end{tabular}




\begin{tabular}{|c|c|c|c|}
\hline NEG & & \multicolumn{2}{|c|}{ PX.GEN.3SG possessive suffix genitive } \\
\hline $\begin{array}{l}\text { NEG } \\
\text { NEG.AUX }\end{array}$ & $\begin{array}{l}\text { negatıve suffix } \\
\text { negative auxiliary }\end{array}$ & PX.GEN.3SC & possessive suftix genitive \\
\hline NLZ & nominalization & & 3 singular possessor \\
\hline PERF & perfect & PX.PL.1PL & possessive suffix nominative \\
\hline PP & postposition & & series plural possessum, \\
\hline $\mathrm{PROB}_{\mathrm{PST}}$ & past probabilative mood & & 1 plural possessor \\
\hline PROL & prolative case & R.3SG & vX conjugation III \\
\hline PST & general past & SG.3DU & vx conjugation II \\
\hline PTCL & particle & TRSL & translative-essive case \\
\hline PTCP.PFT & perfective participle & & \\
\hline Tundra Er & nets & & \\
\hline $\mathrm{CN}$ & connegative & IROG.? & currently unclassifiable \\
\hline CON & converb & & interrogative element \\
\hline DUR & durative aspect & IROG.AOR & interrogative mood aorist \\
\hline e. g. PL.1SG & $\mathrm{vx}$ conjugation II & IROG.PST & interrogative mood past \\
\hline e.g. .1SG & vx conjugation I & LAT & lative case (on postposition) \\
\hline e. g. [GEN] & non-possessive case & $\mathrm{LAT}_{\text {poss }}$ & lative allomorph \\
\hline e.g. R.3SG & vx conjugation III & & possessive declination \\
\hline FREQ & frequentative aspect & NEG.AUX & negative auxiliary \\
\hline FUT & future tense & PX.GEN & PX belonging to genitive series \\
\hline Nganasan & & Tundra $N$ & Jenets \\
\hline ACC & accusative & $-2 S G$ & vx conjugation I \\
\hline AOR & aorist & $2 S G$ & pronoun \\
\hline $\mathrm{CN}$ & connegative & IROG & interrogative mood \\
\hline IROG & interrogative mood & PRO.LOC & interrogative locative pronoun \\
\hline NEG.AUX & negative auxiliary & & \\
\hline & possessive suffix & & \\
\hline
\end{tabular}

\section{Origin of examples}

Forest Enets [text:line] = Сорокина, И.П. \& Болина, Д.С. 2005: Энецкие тексты. Санкт-Петербург: Наука. Е.g. [ZNB Weekend] = data deriving from transcribed narrative; e. g. [ZNB I 32] = data deriving from elicitation.

Tundra Enets Helimski = Хелимский, Е. А. (n. d.): Выписей по энецкой грамматике. Nganasan $\quad \mathrm{NgJa}=$ Жовницкая, С. Н. (n. d.): Нганасанский язык. Красноярск. Tundra Nenets [TMP I 1 ] = data deriving from elicitation. 


\section{Literature}

DeLAnCEy, ScotT 1997: Mirativity: the grammatical marking of unexpected information. Linguistic Typology 1: 33-52.

Janhunen, Juha 1998: Samoyedic. - D. Abondolo (ed.): The Uralic Languages. London - New York: Routledge. 457-479.

Katzschmann, Michael 2008: Chrestomathia Nganasanica. Norderstedt: Books on Demand $\mathrm{GmbH}$.

LABANAUSKAS 2002 = Лабанаускас, К. И.: Отдельные записи по грамматике диалекта маду сделанные в пос. Воронцово в 1973-1974 гг. - Лабанаускас, К. И. (ed.): Родное слова - энецкие песни, сказки, исторические предания, традиционные рассказы, мифы. Санкт-Петербург: Просвещение. 40-62.

Miestamo, Matti 2005: Standard Negation. The Negation of Declarative Verbal Main Clauses in a Typological Perspective. Empirical Approaches to Language Typology 31. Berlin: Mouton de Gruyter.

Mikola, Tibor 2004: Studien zur Geschichte der samojedischen Sprachen - aus dem Nachlass herausgegeben von Beáta Wagner-Nagy. Studia Uralo-Alatica 45. Szeged: SzTE Finnisch-Ugrisches Institut.

SiEgL, Florian 2012: Yes/no questions and the interrogative mood in Forest Enets. Tiina Hyytiäinen, Lotta Jalava, Janne Saarikivi \& Erika Sandman (eds): Per Urales ad Orientem. Iter polyphonicum multilingue. Festskrift tillägnad Juha Janhunen på hans sextioårsdag den 12 februari 2012. Mémoires de la Société Finno-Ougrienne 264. Helsinki: Société Finno-Ougrienne. 399-408.

- 2013: Materials on Forest Enets, an Indigenous Language of Northern Siberia. Mémoires de la Société Finno-Ougrienne 267. Helsinki: Société Finno-Ougrienne.

- (in print): Negation in Forest Enets. - Matti Miestamo, Beáta Wagner-Nagy, Anne Tamm (eds): Negation in Uralic Languages. Typological Studies in Language 108. Amsterdam: Benjamins. 45-73.

Soroкina $2010=$ И. П. Сорокина: Энецкий язык. Санкт-Петербург: Наука.

TerešČEnko 1966 = Н. М. Терещенко: Энецкий язык. - В. И. Лыткин (ed.): Языки народов СССР Том 3: Финно-угорские и самодийские языки. Москва: Наука. 438-457.

- 1973: Синтаксис самодийских языков. Ленинград: Наука.

- 1979: Нганасанский язык. Ленинград: Наука.

Wagner-Nagy, BeÁta 2011: On the Typology of Negation in Ob-Ugric and Samoyedic languages. Mémoires de la Société Finno-Ougrienne 262. Helsinki: Société FinnoOugrienne. 